\title{
Is Closure of Hartmann's Colostomy a Safe Operation?
}

\section{Harttmann Kapatılması Güvenli Bir Operasyon mu?}

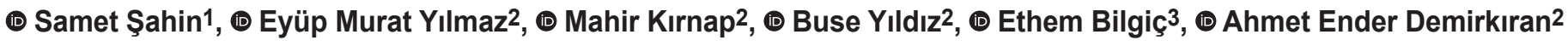 \\ ${ }^{1}$ Muğla Sıtkı Koçman University Faculty of Medicine, Department of General Surgery, Muğla, Turkey \\ ${ }^{2}$ Aydın Adnan Menderes University Faculty of Medicine, Department of General Surgery, Aydın, Turkey \\ 3Didim State Hospital Clinic of General Surgery, Aydın, Turkey
}

\section{IIIIIIII ABSTRACT}

Aim: Ostomy closure after Hartmann's procedure is a challenging decision for surgeons due to the frequency of postoperative early complications in these patients. The aim of this study was to evaluate whether this operation is safe and to identify the factors associated with complications, based on analysis of a population that underwent Hartmann's procedure.

Method: Ostomy closure patients, operated between January 2016 and December 2020, were included in the study retrospectively. Post-operative complications of the patients were classified by Modified Clavien Dindo (MCD) score.

Results: During the study period 52 patients were eligible for inclusion. Seven (13.5\%) had MCD high grade complication. Univariate analysis indicated a significant association between complication and first operation indication and between intensive care unit admission and first operation reason and also the MCD score. In regression analysis, it was found that an increase in age increased the need for intensive care (odds ratio: 1.046, 95\% confidence interval: 1.004-1.089, $\mathrm{p}=0.032$ ). Moreover, the reason for performing the Hartmann's procedure in the first operation was determined as an independent risk factor for complication development and for intensive care ( $\mathrm{p}=0.001$ and $\mathrm{p}=0.028$, respectively).

Conclusion: Operation of Hartmann's closure is a safe procedure in selected and experienced centres.

Keywords: Complication, Harttmann, ostomy

\section{|||||||||| ÖZ}

Amaç: $\mathrm{Bu}$ hastalarda postoperatif erken komplikasyon sıklı̆̆ı nedeniyle Harttmann prosedüründen sonra ostominin kapatılması cerrahlar için iddialı bir karardır. Bu çalışmanın amacı, Hartmann operasyonu uygulanan hastalarda bu operasyonun güvenli olup olmadığını değerlendirmek ve komplikasyonlarla ilişkili faktörleri ortaya koymaktır.

Yöntem: Ocak 2016-Aralık 2020 tarihleri arasında opere edilen 52 ostomi kapatılma hastası geriye dönük olarak çalışmaya dahil edildi. Tüm hastalardan yazılı olarak onam alındı. Hastaların ameliyat sonrası komplikasyonları Modifiye Clavien Dindo (MCD) skoruna göre sınıflandırıldı.

Sonuç: Elli iki hastanın 7'sinde MCD yüksek dereceli komplikasyon vardı. Tek değişkenli analizde komplikasyon ile ilk operasyon endikasyonu arasında anlamlı bir ilişki vardı, ayrıca yoğun bakıma yatış ile ilk operasyon nedeni ve MCD skoru arasında da anlamlı bir ilişki vardı. Regresyon analizinde yaş artışının yoğun bakım ihtiyacını arttırdığı bulundu (odds ratio: 1,046, \%95 güven aralığı: 1,004-1,089, p=0,032). Ayrıca ilk ameliyatta Hartmann işleminin yapılma nedeni komplikasyon gelişimi ve yoğun bakım için bağımsız bir risk faktörü olarak belirlendi (sırasıyla; p=0,001, $\mathrm{p}=0,028)$.

Sonuç: Hartmann kapatma operasyonu, seçilmiş ve deneyimli merkezlerde güvenli bir prosedürdür.

Anahtar Kelimeler: Komplikasyon, Hartmann, ostomi

\section{Introduction}

Hartmann's procedure is an operation in which the rectosigmoid colon is resected, rectal stump is left distally and the proximal border is opened from the skin to create an end colostomy. ${ }^{1}$ This technique is frequently preferred in urgent surgery of colorectal cancers with complications such as perforation and obstruction. The advantages of this approach include immediate resection of the diseased colon, 
safety of avoiding an anastomosis, more rapid convalescence and a shorter hospital stay. The disadvantages are the low reversal rate-in the region of $60 \%^{2}$ and the complications associated with the second stage. ${ }^{3}$ In addition, this technique is frequently preferred in cases of complicated diverticulitis, sigmoid volvulus or colon trauma. ${ }^{4}$ Hartmann's procedure is a surgical method used not only in urgent surgery or damage control surgery, but also in patients with comorbidities to reduce operation time and to prevent complications due to anastomosis. ${ }^{5}$ Although it is preferred to attempt primary anastomosis in colon resections as often as possible, since it will eliminate the need for surgery, the presence of panperitonitis or patient comorbidities may make it necessary to apply Hartmann's procedure, especially in emergency conditions and in cases where preoperative preparation is not sufficient. However, ostomy closure is a challenging decision for surgeons, due to the frequency of postoperative early complications in patients undergoing Hartmann's procedure. Although Hartmann's procedure or other stoma procedures are currently mostly carried out on the understanding that they will be temporary, stoma closure is still not possible in half of cases. ${ }^{6}$, which may be due to age and the various comorbidities of individual patients. This procedure, which was first applied by Gervin and Fischer ${ }^{1}$ in 1879, was first described in 1921 by the eponymous Hartmann as a procedure for resection of rectal cancers. ${ }^{7}$ Nevertheless, the first practical application of Hartmann's closure method was only possible in 1950 and, with the increase in experience in laparoscopic surgery, laparoscopic Hartmann's closure was first described in 1993. The frequency of complications varies widely from $0.8 \%$ to $40 \%$ from centre to centre. ${ }^{5}$ This suggests that greater success rates are possible when using Hartmann's procedure or closure, with lower complication rates, but the variables which may affect success should be identified. The aim of this study was to evaluate whether this operation is safe and to reveal the factors associated with complications, based on a population of patients who underwent Hartmann's procedure in our clinic or another health institution and who had the Hartmann's closure in our clinic.

\section{Materials and Methods}

This was designed as a retrospective observational study through data collection and includes 52 patients who underwent Hartmann's closure between the dates of January 2016 and December 2020. Hospital Ethics Committee approval was obtained (Non-interventional Clinical Research Ethics Committee, date: 21.12.2020, number: 2020/233) and the study was prepared in accordance with the Declaration of Helsinki. Patient data were obtained from the hospital information management system; incomplete data were collected by contacting patients by telephone.
Inclusion criteria of the study were:

- Patients underwent Hartmann's procedure for both benign or malignant reasons;

- Patients underwent the first operation either at our clinic or another health institution;

- All patients had post-operative follow-up at our clinic after Hartmann's closure,

- All patients had Hartmann's closure performed by the same surgeon;

- All patients underwent anastomosis which was performed using a circular stapler.

Exclusion criteria were:

- Patients transferred to another centre in the postoperative period after the Hartmann closure;

- Patients whose data were not available;

- Patients who underwent laparoscopic closure of the Hartmann or who were converted into open surgery;

- Cases in which anastomosis was performed manually.

In all patients operated because of malignancy, the condition of the rectal stump was evaluated by colonoscopic evaluation before closure of Hartmann. After the Hartmann's procedure in patients first operated under emergency conditions, the presence of synchronous tumours was evaluated by colonoscopy. Also, bowel preparation was carried out in all patients before the closure of the Hartmann.

Patients' ender, age, indication for Hartmann's procedure, duration between the two operations, length of hospital stay after closure of the Hartmann operation, requirement for intensive care unit (ICU) care and duration of ICU stay, ASA scores of the patients, complication type in patients who develop complications, Modified Clavien Dindo (MCD) complication score, and instances of mortality were evaluated. While calculating the hospitalization and ICU periods of the patients, the day of operation was accepted as the first day of hospitalization. For ASA scores, the score in preoperative anaesthesia consultation was accepted. MCD score was calculated retrospectively, based on patient progress and epicrisis information. Deaths in patients up to 30 days postoperatively or deaths associated with surgery were considered as operation-related mortality. All cases with prolonged hospitalisation, or that required additional medical or surgical intervention were considered as complication. Intestinal content coming from the abdominal drain or incision site and/or contrast agent extravasation into the abdomen in contrast-enhanced computed tomography using either oral or rectal contrast or detecting abscess content were defined as anastomotic leak. Eventration occurred in one patient during postoperative hospitalization and this was also considered as a complication of incisional hernia. 


\section{Statistical Analysis}

After the data were compiled retrospectively using Microsoft Excel® (Microsoft Corporation, Santa Rosa, CA., USA), statistical analysis was performed with SPSS ${ }^{\circledR}$ software for Windows, version 22 (IBM Inc., Chicago, IL., USA). Distribution widths of the data were evaluated by Kolmogorov-Smirnov and Shapiro-Wilk tests. Mean and standard deviation values for data that conformed to normal distribution and median and interquartile ranges were calculated for non-parametric data. The evaluation of categorical data was done by chi-square and Fisher's exact test. Analysis of nonparametric quantitative data was performed using Mann-Whitney U test. Binary logistic regression was used for multivariate analysis. A p value $<0.05$ was assumed to indicate significance.

\section{Results}

Of the 52 patients included in the study, 16 (25.8\%) were female and $36(58.1 \%)$ were male. The mean age of the patients was $59.08 \pm 15.92$ years. When the ASA scores were evaluated, six (11.5\%) patients had been operated with ASA1,12 (23.1\%) with ASA-2, 33 (63.5\%) with ASA-3, and one (1.9\%) with ASA-4. Three (5.7\%) patients had died during the post-operative follow up.

When the reasons for undertaking the Hartmann procedure were evaluated, benign conditions and malignancy were present in similar proportions. Diverticulitis perforation was the most common cause among benign conditions. The first operation reasons for the patients are presented in Table 1.

For all patients, the mean duration of hospitalisation after the closure of the Hartmann was $13.04 \pm 10.33$ days. While $24(46.2 \%)$ patients did not require intensive care followup in the post-operative period, 28 patients (53.8\%) did. Median (interquartile range) duration in the ICU was 4 (2.25-7) days.

Discharge was made in 23 (44.2\%) patients after normal procedures. MCD scoring was performed in the remaining
29 patients for complications after the Hartmann closure. In these Grade 1 MCD score was present in $14(26.9 \%)$ and Grade 2 MCD score was present in eight (15.4\%) patients. In addition, MCD score was Grade 3 in two (3.8\%) patients, Grade 4 in two (3.8\%) patients, and Grade 5 in three (5.8\%) patients. Clinical characteristics of the patients with high MCD scores are shown in Table 2.

Patients with no complications or with low-grade MCD scores (Grade 1, 2) were defined as Group $1(n=45)$, and patients with high-grade MCD scores (Grades 3-5) as Group $2(n=7)$. When the demographic, preoperative, perioperative and postoperative data of these two groups were evaluated, complications were significantly more likely in patients operated for volvulus $(\mathrm{p}=0.002)$. Hospitalization and ICU duration were significantly longer in Group 2 patients ( $\mathrm{p}<0.001$ for both). Mortality was also significantly higher in Group 2 patients $(\mathrm{p}=0.002)$. Univariate analysis of the two groups are summarized in Table 3.

Just under half of the patients $(n=24,46.2 \%)$ did not need ICU care in the post-operative period, while 28 patients were admitted to ICU. Patients needing ICU were significantly older ( $\mathrm{p}=0.04)$ and also had higher MCD scores ( $\mathrm{p}=0.016)$. ICU requirement was higher in patients who were operated because of either colorectal cancer or volvulus. Table 4

Table 1. Etiology in patients undergoing Hartmann procedure (first operation)

\begin{tabular}{|lll|}
\hline & $\mathbf{n}$ & $(\%)$ \\
\hline Colorectal cancer & 27 & 51.9 \\
Diverticulitis perforation & 17 & 32.7 \\
Trauma & 4 & 7.7 \\
Volvulus & 4 & 7.7 \\
Benign etiology & 25 & 48.1 \\
Malign etiology & 27 & 51.9 \\
n: Number of patients & &
\end{tabular}

Table 2. Follow-up and mortality results of patients with MCD high grade complications

\begin{tabular}{|c|c|c|c|c|}
\hline Complication type (n) & First operation reason & $\begin{array}{l}\text { Length of stay in hospital/ } \\
\text { ICU (days) }\end{array}$ & MCD score & Mortality \\
\hline \multirow{4}{*}{ Anastomotic leak (4) } & pl sigmoid volvulus & $\mathrm{pl}: 43 / 13$ & Grade 4 & No \\
\hline & p2 sigmoid volvulus & $\mathrm{p} 2: 57 / 50$ & Grade 5 & Exitus \\
\hline & p3 diverticulitis perforation & p3: $36 / 22$ & Grade 5 & Exitus \\
\hline & p4 sigmoid volvulus & p4: 42/13 & Grade 5 & Exitus \\
\hline Ileum perforation ( 1 ) & Tumor & $33 / 18$ & Grade 4 & No \\
\hline Rectovaginal fistula (1) & Tumor & $15 / 4$ & Grade 3 & No \\
\hline Incisional hernia (1) & Trauma & $7 / 0$ & Grade 3 & No \\
\hline
\end{tabular}

n: Number of patients, p: Patient, ICU: Intensive care unit, MCD: Modified Clavien Dindo score 
shows a comparison of characteristics of those patients who did or did not need ICU.

Regression analysis assessment of the effect of demographic and pre-operative clinicopathological characteristics for predicting the development of complications and the need for ICU showed that increased age had no effect on development of complications ( $\mathrm{p}=0.077$ ), but did increase ICU requirement [odds ratio (OR): 1.046, 95\% confidence interval $(\mathrm{CI})$ : 1.004-1.089, $\mathrm{p}=0.032]$. The reason for performing Hartmann's procedure in the first operation was an independent risk factor for complication development and for ICU requirement ( $\mathrm{p}=0.001$ and $\mathrm{p}=0.028$, respectively). The risk of developing complications was found to be significantly higher in patients who underwent Hartmann's procedure for sigmoid volvulus compared to diverticulitis perforation (OR: $0.001,95 \% \mathrm{CI}: 0-0.077, \mathrm{p}=0.002$ ) and presence of tumor (OR: 0.002, 95\% CI: 0-0.044, p<0.001). In addition, the risk of going to ICU was found to be significantly higher in patients who underwent Hartmann due to sigmoid volvulus compared to diverticulitis perforation (OR: $0.073,95 \%$ CI: 0.007-0.773, p=0.030).
There was a correlation between increasing ASA score and an increasing risk of complications (OR: 17.02, 95\% CI: 1.155-250.871, $\mathrm{p}=0.039$ ) but the ASA score was not able to predict the risk of going to intensive care ( $\mathrm{p}=0.678$ ). It was found that, as the duration between the two operations increased, the risk of developing complications decreased (OR: 1.163, 95\% CI: 1.004-1.346, p=0.044) (Table 5).

\section{Discussion}

This study showed that the procedure of Hartmann closure is a safe operation, especially in selected patient groups. Hartmann's procedure is currently still being performed and is likely to continue. However, acceptance of this procedure by surgeons as a last resort procedure brings a mandatory requirement for careful patient selection, in order to shorten the operation time and to avoid the risk of anastomotic leak in those with comorbidities.

The mean age of the patients in our study was 59 years and $65 \%$ of the patients had ASA $\geq 3$ which is similar to earlier reports. ${ }^{8,9,10}$ However, it seems self-evident that elderly

Table 3. Parameters associated with complication in two groups stratified by Modified Clavien Dindo score. Group 1 had no complications or MCD score 1 or 2, Group 2 had MCD score of $\geq 3$

\begin{tabular}{|c|c|c|c|}
\hline & Group $1(n=45)$ & Group $2(n=7)$ & $\mathrm{p}$ value \\
\hline Median age (IQR) & $58(48.5-73)$ & $67(35-72)$ & 0.703 \\
\hline \multicolumn{4}{|l|}{ Gender n (\%) } \\
\hline Female & $14(31.1)$ & $2(28.6)$ & 0.078 \\
\hline Male & $31(68.9)$ & $5(71.4)$ & \\
\hline \multicolumn{4}{|l|}{ Reason for Hartmann n (\%) } \\
\hline Tumor & $25(55.6)$ & $2(28.6)$ & 0.002 \\
\hline Diverticulitis & $16(35.6)$ & $1(14.3)$ & \\
\hline Trauma & $3(6.7)$ & $1(14.3)$ & \\
\hline Volvulus & $1(2.2)$ & $3(42.9)$ & \\
\hline Median duration between first and second procedure (IQR), months & $9(6-15)$ & $12(8-15)$ & 0.268 \\
\hline Median duration of hospital stay (IQR), days & $9(8-12)$ & $36(15-43)$ & $<0.001$ \\
\hline Median duration of ICU stay (IQR), days & $0(0-3.5)$ & $13(4-22)$ & $<0.001$ \\
\hline \multicolumn{4}{|l|}{ ASA score n (\%) } \\
\hline 1 & $5(11.1)$ & $1(14.3)$ & 0.078 \\
\hline 2 & $11(24.4)$ & $1(14.3)$ & \\
\hline 3 & $29(64.4)$ & $4(57.1)$ & \\
\hline 4 & 0 & $1(14.3)$ & \\
\hline \multicolumn{4}{|l|}{ Mortality n (\%) } \\
\hline No & $45(100)$ & $4(57.1)$ & 0.002 \\
\hline Exitus & 0 & $3(42.9)$ & \\
\hline
\end{tabular}

ICU: Intensive care unit, ASA: American Society of Anaesthesiologist, IQR: Interquartile range 
Table 4. Parameters associated with requirement for ICU

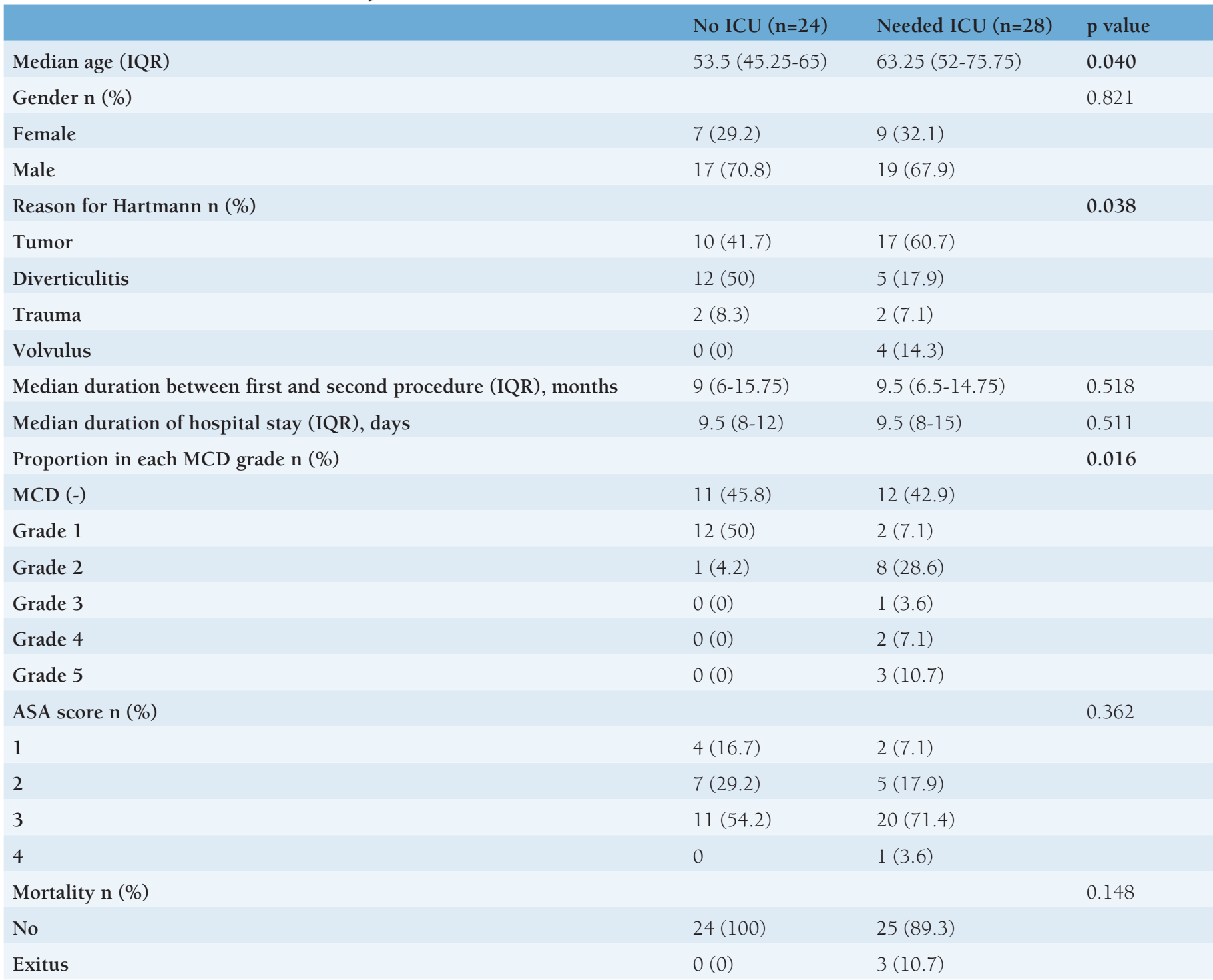

ICU: Intensive care unit, MCD: Modified Clavien Dindo, ASA: American Society of Anaesthesiologist, IQR: Interquartile range

Table 5. Multiple logistic regression analysis in predicting development of complications and the need for ICU

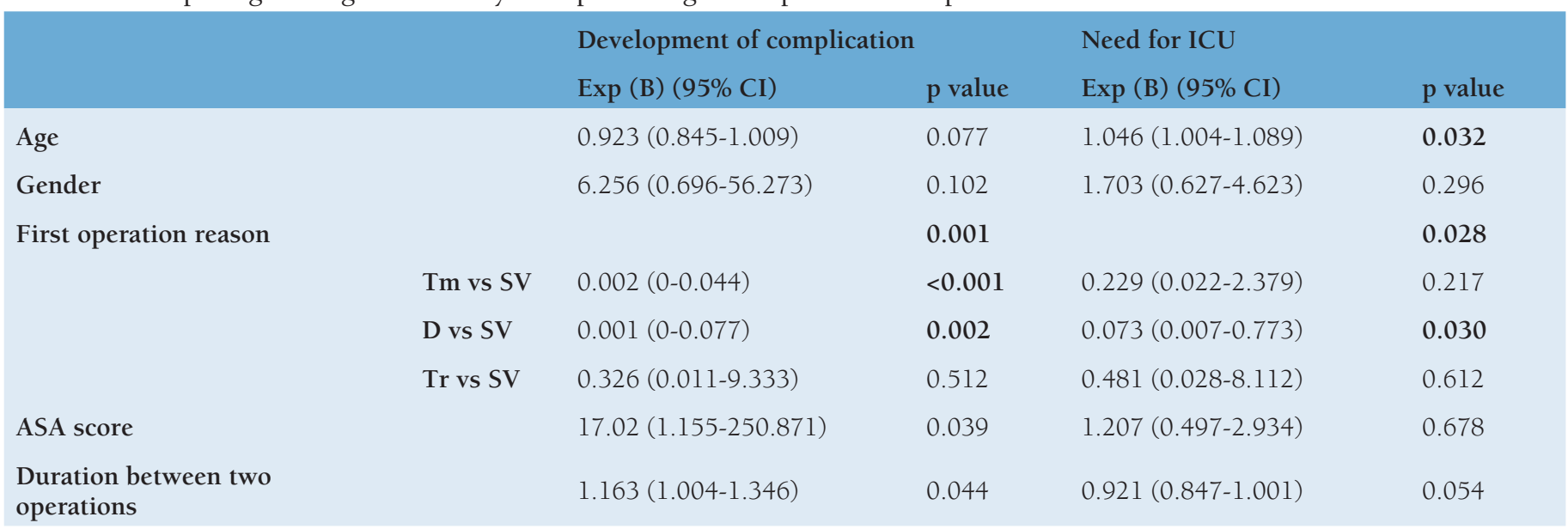

Tm: Tumor, D: Diverticulitis perforation, SV: Sigmoid volvulus, ASA: American Society of Anaesthesiologists 
patients, who are also more likely to have comorbidities and thus are frequently operated for emergency reasons, such as pan-fecalith, perforation, and ileus, will be at a disadvantage due to the nature of the Hartmann's closure operation. This should be taken into account while evaluating whether the Hartmann's closure procedure is safe. In our cohort when indications for the Hartmann's procedure were evaluated, the proportion of benign and malignant indications were similar. This contrasts with some reports in the literature, with some studies reporting the most common reason for Hartmann's procedure to be colorectal cancers ${ }^{11,12}$, while in others diverticulitis perforation is the most common cause. ${ }^{11}$ However, in patients with malignancy, the addition of adjuvant chemoradiotherapy causes anxiety in surgeons for anastomotic leaks after stoma closure and this tends to discourage proposing stoma closure to these patients. However, the idea of living with a stoma for life is more difficult in patients operated for benign reasons. Thus the motivation for Hartmann's closure operation is higher in this group whose disease-free survival is expected to be longer, compared to patients operated because of malignancy. Therefore, in studies reporting cases where the first and second operations were followed in a single center, it was found that some patients did not undergo Hartmann's closure surgery. ${ }^{13,14}$ In a meta-analysis of 35 studies, the most common reasons given for not performing Hartmann's closure were high ASA score, patient reluctance, metastatic disease, and high age. ${ }^{10}$ In the same study, the most common first operation indication in those undergoing Hartmann's closure was diverticulitis perforation, which is similar to our study. ${ }^{10}$

The high-grade complication rate in our study was $13.4 \%$ which is in keeping with previously reported complication frequencies (3-50\%). ${ }^{10}$ It is noteworthy that in 3 of 7 patients with high-grade complications, the first operation indication was sigmoid volvulus. Resection in a longer segment in the sigmoid volvulus, and consequently higher anastomosis tension after closure of Hartmann may be a reason for this. Although high vascular ligation in mesocolic excision is recommended, which significantly increases mobilization in the proximal loop ${ }^{15}$, avoiding these steps in benign operations such as sigmoid volvulus due to the concern of deterioration of the vascular structure may cause restriction of mobilization in the proximal region and the line of the anastomosis to remain tight. Structural impairment of the colonic vascular bed in patients with sigmoid volvulus due to a narrow-based mesocolon ${ }^{16}$ may explain nourishment problems in the anastomosis line after the closure of the Hartmann. One of our cohort developed incisional hernia complication although their first operation indication was trauma. Accordingly, Hartmann's closure operation was performed by using the same incision in the second operation of the patient who had a wide laparotomy in the first operation. Incisional hernia complication due to wide laparotomy in this patient is compatible with the literature. ${ }^{17}$ Colorectal cancer as a primary pathology may have negatively affected the healing process due to adjuvant therapies in patients with ileum perforation and rectovaginal fistula. In the literature review, these complications are considered among the complications expected to be encountered in colorectal cancer. ${ }^{18,19}$

In our cohort, three patients died in the postoperative period and the main complication determining mortality in all of these patients was anastomotic leak. It is remarkable that two of these patients underwent the Hartmann procedure due to sigmoid volvulus and the other because of diverticular disease; all three had benign indications for the first operation. Mortality rates in the literature were variable and often higher than our study, and varied from $0.9 \%$ to $15 \% .^{14,20}$

Univariate analysis identified patient's age, ASA risk scores in the preoperative period and first operation indications as being associated with the development of complications. ASA scores were higher in patients with MCD high-grade complications at the $10 \%$ significance level, while sigmoid volvulus as a first operation indication was significant at the $5 \%$ level. In our study patients with high-grade complications were older patients. On regression analysis older age, higher ASA risk score and first operation indication were found to be independent parameters predicting the development of complications, which is similar to previous reports. ${ }^{21,22}$ However, the ASA score was not found to be related to the length of stay in ICU. Having sufficient capacity in ICU in our clinic may have led us to determine wider indications in terms of monitoring patients in intensive care. Although ICU beds comprise of only $2-8 \%$ of the bed capacity of hospitals, patients to be observed (20-77\%) may be seen in ICU during additional examinations and treatments. ${ }^{23}$ Hospitalization, ICU follow-up duration and mortality were significantly higher in the patient group with complications, as expected. Duration of hospitalization and the need for ICU were similar to the literature. ${ }^{24}$ The most common cause of mortality in patients undergoing Hartmann's closure is considered to be septic complications due to anastomotic leak and postoperative abscesses. ${ }^{25,26}$ Gender and duration between the two operations weren't related to high grade complications after closure of the Hartmann, as has previously been reported. ${ }^{10}$

\section{Study Limitations}

Limitations of our study should be noted. Our clinic is a specialist colorectal surgery center where operations are 
frequently performed and is a tertiary reference clinic. Therefore, our patient group consisted of more difficult patients, with more comorbidities and higher ASA scores, compared to the literature. ${ }^{10}$ In addition, the retrospective nature of the design introduced bias in predicting complications and mortality risk. Despite this, the mortality and complication rates are similar or even lower when compared to the literature.

\section{Conclusion}

In conclusion, we believe that operation of Hartmann's closure is a safe procedure in selected and experienced centers. ASA score and first operation indication emerged as independent risk factors for serious complication in our cohort. There is a need for larger, prospective, multicenter studies to eliminate the patient bias inherent in our retrospective analysis of a tertiary center patient population in order to accurately identify risk factors and to confirm the findings reported here.

\section{Ethics}

Ethics Committee Approval: Aydın Adnan Menderes University Faculty of Medicine Non-Invasive Clinical Research Ethics Board (date: 17.02.2020/number: 53043469-050.04.04).

Informed Consent: Obtained.

Peer-review: Internally peer reviewed.

\section{Authorship Contributions}

Surgical and Medical Practices: S.S.,, E.M.Y., M.K., A.E.D., Concept: M.K., E.B., Design: B.Y., E.B., Data Collection or Processing: S.Ş., E.M.Y., B.Y., Analysis or Interpretation: M.K., B.Y., Literature Search: S.S.., E.M.Y., A.E.D., Writing: S.Ş., E.M.Y., M.K., B.Y., E.B., A.E.D.

Conflict of Interest: No conflict of interest was declared by the authors.

Financial Disclosure: The authors declared that this study received no financial support.

\section{References}

1. Gervin A, Fischer RP. Identification of the rectal pouch of Hartmann. Surg Gynecol Obstet 1987;164:177-178.

2. Koruth N, Krukowski ZH, Youngson GG, Hendry WS, Logie JR, Jones PF, Munro A. Intra-operative colonic irrigation in the management of left-sided large bowel emergencies. Br J Surg 1985;72:708-711.

3. Bakker F, Hoitsma HF, Den Otter G. The Hartmann procedure. Br J Surg 1982;69:580-582

4. Kang JH, Kang BM, Yoon SN, Kim JY, Park JH, Oh BY, Kim JW. Analysis of factors affecting reversal of Hartmann's procedure and post-reversal complications. Sci Rep 2020;10:1-8.

5. Christou N, Rivaille T, Maulat C, Taibi A, Fredon F, Bauvier S, Fabre A, Derbal S, Durand-Fontanier S, Valleix D, Robert-Yap J, Muscari F, Mathonnet M. Identification of risk factors for morbidity and mortality after Hartmann's reversal surgery-a retrospective study from two French centers. Sci Rep 2020;10:1-8.

6. Toro A, Ardiri A, Mannino M, Politi A, Di Stefano A, Aftab Z, Abdelaal A, Arcerito MC, Cavallaro A, Cavallaro M, Bertino G, Di Carlo I. Laparoscopic reversal of Hartmann's procedure: state of the art 20 years after the first reported case. Gastroenterol Res Pract 2014;2014:530140.

7. Van Eijck F, van Veen RN, Kleinrensink GJ, Lange JF. Hartmann's gallbladder pouch revisited 60 years later. Surg Endosc 2007;21:11221125.

8. Brathwaite S, Latchana N, Esemuede I, Harzman A, Husain S. Risk factors for surgical site infection in open and laparoscopic Hartmann closure: a multivariate analysis. Surg Laparosc Endosc Percutan Tech 2017;27:51-53.

9. Sücüllü İ, Demirbaş S, Yücel E, Filiz Aİ, Kurt Y, Akın ML. Hartmann's Procedure: Should it be Performed? Turk J Colorectal Dis 2007;17:22-26.

10. van de Wall BJM, Draaisma WA, Schouten ES, Broeders IAMJ, Consten ECJ. Conventional and laparoscopic reversal of the Hartmann procedure: a review of literature. J Gastrointest Surg 2010;14:743-752.

11. Desai DC, Brennan EJ, Reilly JF, Smink Jr RD. The utility of the Hartmann procedure. Am J Surg 1998;175:152-154.

12. Seah DW, Ibrahim S, Tay KH. Hartmann procedure: is it still relevant today? ANZ J Surg 2005; 75:436-440.

13. Bostancı H, Yüksel O, Dikmen K, Sahin T, Dikmen A, Sare M. The Role of Hartmann's Procedure in Emergency Left Colon Pathologies: Our Clinical Experience. Turk J Colorectal Dis 2017;17:191-195.

14. Barbieux J, Plumereau F, Hamy A. Current indications for the Hartmann procedure. J Visc Surg 2016;153:31-38.

15. Heald RE, Husband EM, Ryall RD. The mesorectum in rectal cancer surgery-the clue to pelvic recurrence? Br J Surg 1982;69:613-616.

16. Lal SK, Morgenstern R, Vinjirayer EP, Matin A. Sigmoid volvulus an update. Gastrointest Endosc Clin N Am 2006;16:175-187.

17. Erkent M, Şahiner İT, Kendirci M, Topçu R. Determination of Risk Factors in Incisional Hernia Development. Hitit Med J 2019;1:15-17.

18. Rex JC, Khubchandani IT. Rectovaginal fistula: complication of low anterior resection. Dis Colon Rectum 1992;35:354-356.

19. Taylor GW, Jayne DG, Brown SR, Dewberry SC, Parker MC, Guillou PJ. Adhesions and incisional hernias following laparoscopic versus open surgery for colorectal cancer in the CLASICC trial. Br J Surg 2010;97:7078

20. Kartal K, Citgez B, Koksal MK, Besler E, Akgun IEE, Mihmanli M. Colostomy reversal after a Hartmann's procedure Effects of experience on mortality and morbidity. Ann Ital Chir 2019;90:539-544

21. Albarran SA, Siomens Ch, Takeh H, da Costa PM. Restoration of digestive continuity after Hartmann's procedure. Hepatogastroenterology 2004;51:1045-1049

22. Roque-Castellano C, Marchena-Gomez J, Hemmersbach-Miller M, AcostaMerida A, Rodriguez-Mendez A, Fariña-Castro R, Hernandez-Romero $\mathrm{J}$. Analysis of the factors related to the decision of restoring intestinal continuity after Hartmann's procedure. Int J Colorectal Dis 2007;22:10911096.

23. Clark K, Normile LB. Critical care admissions criteria in community based hospitals: a pilot study with implications for quality management. J Nurs Care Qual 2000;15:32-41

24. Banerjee S, Leather AJM, Rennie JA, Samano N, GonzalezJG, Papagrigoriadis S. Feasibility and morbidity of reversal of Hartmann's. Colorectal Dis 2005; 7:454-459

25. Bell C, Asolati M, Hamilton E, Fleming J, Nwariaku F, Sarosi G, Anthony T. A comparison of complications associated with colostomy reversal versus ileostomy reversal. Am J Surg 2005; 190:717-720.

26. Geoghegan J, Rosenberg IL. Experience with early anastomosis after the Hartmann procedure. Ann R Coll Surg Engl 1991;73:80. 